\title{
Wiese Thomas
}

\section{A literature review of Happiness and Economics and guide to needed research}

\begin{abstract}
Happiness and Economics as a new branch of behavioural economics has had a major impact on economic theory and economic policy: Several studies have been published in the last 20 years in leading journals. Furthermore, several governments have decided to collect data about the well-being of their citizens. The author claims that utility cannot only be measured by the choices individuals do: Reported happiness and life satisfaction data is also an acceptable empirical estimate for individual utility. Consequently, happiness research can bear new knowledge and important understanding of human welfare. Therefore, this paper gives an overview of the existing literature. Methods and approach of scholars is critically analysed and shortcomings are discussed. Thereafter, findings on major economic issues like growth, unemployment and inflation are presented. Besides, governmental policy and implications for society are debated. Lastly, future research possibilities are mentioned.
\end{abstract}

Journal of Economic Literature (JEL) Classification: D60 D63 I31

Keywords: Happiness, Life Satisfaction, Income, Inflation, Unemployment, Trend Growth

Greater happiness for the greatest number of citizens seems to be a sound goal for public policy. In the personal sphere too, the pursuit of happiness has been the aim of many of us. Before 1950 it was exclusively philosophers and theologians who focused on the question of how to live a good life. However, for more than 60 years the mainstream social sciences have been researching the topic. To obtain quantifiable results, data about people's well-being was gathered in countless surveys which asked about individuals' life satisfaction, feelings and other states of mind. These social, cognitive and emotional factors are very important for the new branch of economics called behavioral economics. This is necessary because "economics is a science of thinking in terms of models joined to the art of choosing models which are relevant to the contemporary world" (Keynes 1938). In behavioral economics life satisfaction data is seen as a certain utility notion and consequently the effects of economic situations can be analyzed in this new framework. It is important to note that the rationality of human beings, expressed in the concept of the "homo economicus", is challenged.

It has been observed that higher income levels have not succeeding in lifting life satisfaction measures. For instance, the United States increased the level of GDP per capita dramatically in the last century so the average household could enjoy the benefits of a 
car, color TV, personal computer, etc. Following the main assumptions of the discipline of economics this should have led to a massive increase in satisfaction with life but counter-intuitively the level has remained stable. Hence, the study of happiness is of major importance for the field of economics.

In this paper, the author intends to highlight the current state of art in the field. Firstly, the question why happiness and economics is an important branch of economics will be discussed. Special focus will be placed on how life satisfaction can be seen as a form of utility. We will also illustrate how research is conducted. Research methods including survey data are presented. Certain shortcomings of this approach will be elaborated, for instance the possible bias in subjectively collected data. This is negatively correlated with the reliability of the results and thus gives ample room to question the conduct of the research. Secondly, the main findings of the past as well as recent literature will be presented. The correlation of happiness with economic variables such as income, inflation and unemployment are shown, especially in comparison with the standard view of economics. Thirdly, advice and outcomes for individuals and governments are debated. Consequently, political and economic consequences will be discussed. Lastly, future research possibilities will be mentioned.

\section{Why happiness and economics is important}

This section will debate the question of why happiness and economics is an important part of the literature and how happiness correlates with what economists call utility. First of all, it is important to note that happiness is a goal in itself; for many even an ultimate goal. Numerous other objectives are merely secondary goals as they follow a different end. For example, money is not wanted for itself - it is the purchasing power it gives the owner which is desired. Many governments have realized this and changed their priorities accordingly: for example, Bhutan a Buddhist kingdom in the Himalaya, tries to maximize Gross National Happiness. They have adopted policies which are counterintuitive in the context of the economic policies of many countries; for instance Lehtonen (2000) reports that Bhutan has stopped its main export product, timber, because they realized that the negative effects on the natural environment and the population would not be compensated for by the revenue stream. Furthermore, the BBC (2010) and The Telegraph (2009) reported that the United Kingdom and France have decided that a measurement of national wellbeing accounts is needed and that it should be a goal of their policies that all citizens are able to pursue their own idea of a happy life.

It is important to remember that most political decisions are problematic in the sense that they bring disadvantages for one group and advantages for another. Pareto improvements are mostly impossible and certain tradeoffs have to be considered. For example, quantitative easing might cause higher inflation on the one hand, but on the other hand unemployment could be reduced. Standard economic models work with the belief in a "homo economicus" model (Persky 1995).The "Economic human" is a concept that is based on the rationality and the self-interest of actors who have the ability to judge the actions they take to move towards defined ends. Even though most economists work with the assumption of a "homo economicus", there are many problems with the concept as empirical surveys and logical arguments criticize the premises of this concept. Thus, standard economic models must 
be critically reviewed due to the shortcomings of the "homo economicus" assumption. Happiness and economics is one possible alternative.

However, happiness research is also challenged as an "unscientific" concept because it does not seem to be an objective science. For example, the measurement of subjective wellbeing can be biased because of cognitive errors and situational interferences. Therefore, it is important to review the history of how the social sciences have accounted for positive and negative outcomes:

Jeremy Bentham (1789) and other utilitarians (Edgeworth 1881) were convinced that utility can be measured cardinally by a device which they called the "hedonometer". For instance, the measurement of brain waves could be used, and objectivity would be ensured as the data is calculated based on an external rule. In contrast, standard economic theory is convinced that utility can simply be measured ordinally (compare Frey and Stutzer 2002a). For example, Hicks (1939) was confident that observed choice is the only way to discover individual utility empirically, and termed this "decision utility". Sen (1986:18) argued that this positivistic view which is very popular in economics "may be due to a mixture of an obsessive concern with observables and a peculiar belief that choice ... is the only human aspect that can be observed."

This standard view is disputed by numerous scholars as their analyses also take into account emotions (Elster 1998), intrinsic motivation (Osterloh and Frey 2000; 2004; 2006), altruism, reciprocity, and cooperation (Schwarze and Winkelmann 2005; Fehr and Gächter 1998; 2000; Fehr and Schmidt 2003; Gächter 2007), status (Frank 1985; 1999; de Botton 2004) and social recognition (Brennan and Pettit 2004). Further, many studies have shown that human preferences are not always stable (for example Allais 1953 and Ellsberg 1961) and that a "projection bias" (Loewenstein et al. 2003) hinders actors as they attempt to maximize their experienced utility. Consequently, it is important to take other measures into account.

Subjective well-being (SWB) is the most commonly used term for happiness in the literature. It was defined by Diener et al. (1999) as a cognitive and affective evaluation of the life someone leads. Further, Szondy (2004:53-72) states that SWB consists of life satisfaction, high positive affectivity and low negative affectivity. Life satisfaction, which is used by most of the surveys, is simply the cognitive component of SWB and excludes positive and negative emotions. A usual life satisfaction survey might ask a respondent: "How satisfied are you with your life as a whole?" Answers are collected according to a 10 point scale where 10 is the highest satisfaction score. See in figure 1 an example for the results of such a survey. The histogram shows the percentage of persons with a particular satisfaction score. It can be seen that US citizens state rather high scores. 


\section{Satisfaction with life in the US}

Figure 1

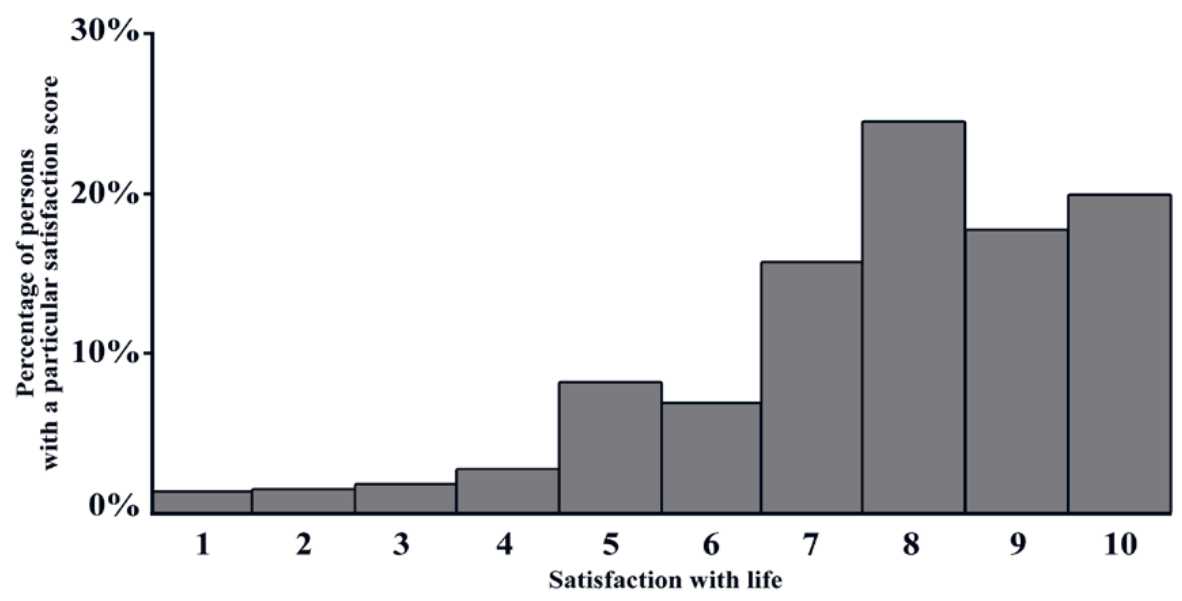

Notes: Own compilation of data for the US taken from the World Values Survey 1995 - 1997.

Frey and Stutzer (2002a:10-26) claim that "people are capable of consistently evaluating their own state of well-being" and that answers to these questions are "the best indicator of happiness". Van Praag and Frijters (1999:427) also share this belief and state that "it is empirically possible for most individuals to evaluate their life as a whole".

In conclusion, the allegation that happiness research is unscientific can be set aside and we can see the importance of an expansion of the field of economics, given its current shortcomings.

\section{Findings on income}

The standard economic literature and, primarily, neoclassical economics state that increased income will enhance utility but marginal utility is diminishing. Higher earnings lead to more consumption possibilities and this directly correlates with raised utility levels. This is the universal law of economic theory. It applies on the individual and the country level as well as over time.

However, Brickman et al. (1978) found out empirically that lottery winners were only slightly happier after one year. The average winner rated his/her life satisfaction as 4.0 on a 5 point scale in comparison with a 3.8 score for the control group which had substantially less wealth. Possible explanations are firstly, winners had less valuable social interactions as many quit their jobs. Secondly, tensions in their social networks arose as people asked them for money. Furthermore, Easterlin (1974) claimed that money does not buy happiness. For countries with enough wealth to meet basic needs, further GDP increases do not contribute to satisfaction with life. This theory is called the "Easterlin-paradox". Other scholars, mainly Betsey Stevenson and Justin Wolfers (2008; 2013), stated that there is a clear link between higher income and increased life satisfaction for individuals as well as for countries. To put 
this controversy into perspective, we present results of happiness research in connection with income.

In the literature the subject has been analysed in three dimensions: firstly, the relative income of different countries; secondly, the relative income of one country over time, and lastly, the relative income of one country at one point in time. Consequently, this section focuses on three questions: Firstly, are rich countries better off than poorer ones? Secondly, does a rise in income over time result in a higher life satisfaction rating? Thirdly, is a rich person more satisfied than a poor person?

On a country scale we observe a positive relationship between higher income and happiness. Richer countries are happier than poorer ones. However, Layard (2003) states that after a certain threshold of around $\$ 15,000$ per capita is reached, additional earnings have no, or only a very small, effect on life satisfaction. It must be argued that rich countries have advantages not only because of their higher purchasing power but also because they have more stable democracies, more secure human rights, smaller differences in the distribution of wealth in the society, and better food, education and health conditions in general (Frey - Stutzer 2002). It is a myth that the inhabitants of poorer countries can live a better life because it is more natural and less stressful. Higher income offers opportunities to choose this kind of lifestyle as well (Frey - Stutzer 2002:76).

For further reading on the relationship between happiness and income between countries see Diener et al. (1995), Veenhoven (1991), Clark et al. (2008), Frey - Stutzer (2010), Easterlin et al. (2010) and Stevenson - Wolfers $(2008,2013)$.

Figure 2

\section{Life satisfaction and Income per capita in Japan between 1958 and 1991}

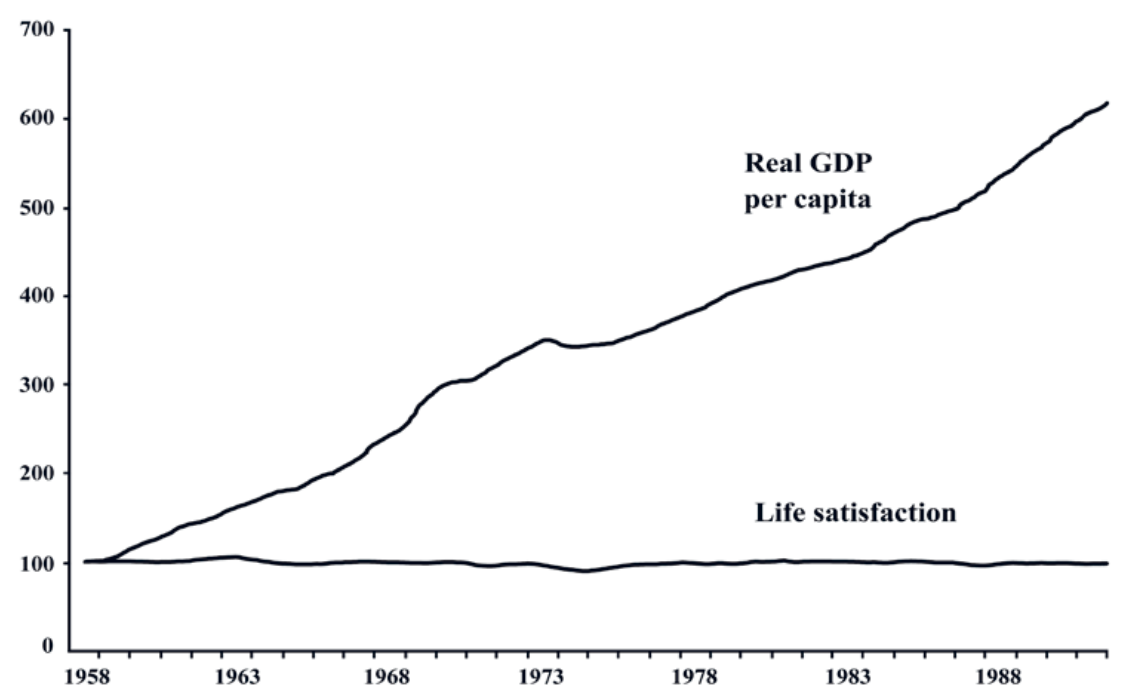

Notes: Own compilation of data taken from the Penn World Tables and the World Database of Happiness.

Next, the paper focuses on income and happiness on an intra-country basis over time. In the literature it has been claimed that rising GDP does not automatically increase well-being. 
For instance, figure 2 shows how life satisfaction and income per capita in Japan (both plotted on the vertical axis) have developed in the period between 1958 and 1991 (displayed on the horizontal axis). The rise in income per capita of an incredible 600 per cent reflects the households' higher purchasing power: In 1991 the standard of living had reached such a high level that the average person was able to afford many things which had not been invented in 1958. Despite this tremendous increase in material possessions average life satisfaction had decreased slightly. In countries like the United States, the United Kingdom and Belgium comparable findings have been investigated (e.g., Blanchflower-Oswald 2000; Lane 1998:462; Myers 2000:61). It is possible that citizens have become accustomed to their new standard of living and their "aspiration level" has changed. Satisfaction needs alteration and vanishes with the same level of consumption. This has staggering consequences: firstly, the same level of consumption will not satisfy over time; secondly, more opportunities create more complex aspirations and consequently, well-being is threatened. In psychology aspiration levels have become familiar concepts since being discussed by both Irwin (1944) and, more recently, by Frederick and Loewenstein (1999).

The paper follows by introducing the relationship between income and individual happiness levels within a country. Di Tella et al. (1999) showed that income and life satisfaction correlate: a greater proportion of individuals from the upper income quartile rated themselves as "quite happy" than those from the lowest quartile. Richer individuals have more opportunities as they are able to afford more goods and hence, enjoy higher status in materialistic societies. Besides, several scholars state that at low levels of income, wellbeing is strongly increased by a rise in income. Beyond a certain limit the effect diminishes. Therefore, the relationship between life satisfaction and income is viewed as "curvilinear" (Frey - Stutzer 2002:83). Moreover, variation in income can explain only a small part of the differences in life satisfaction. For example, Easterlin (2001:468) showed that the simple correlation is only 0.20 . Other factors such as unemployment or health seem to be more important. Personality factors such as how material goods are valued also seem to matter: Sirgy (1997) showed that those who focus on material things are less satisfied with life. At this point is it important to note that a general rise in income does not necessarily improve life satisfaction levels. Especially in developed countries it is questionable whether raising everybody's income would have an impact on reported life satisfaction levels. The reason is that in comparison to others the individual's situation has not improved. This status effect of nominal income is viewed as a "rat race" and has quite negative consequences on life in general. Additionally, others' income can have bad effects on society as envy can grow. The external effect of luxury goods like expensive watches and yachts can be regarded as negative for life satisfaction: firstly, luxuries do not give the owner any additional pleasure because he or she adapts to his or her property and his or her status in the long run. Secondly, luxuries make less wealthy individuals envious and reduce their life satisfaction. Thirdly, luxuries waste resources (Frey - Stutzer 2002). However, Clark and Oswald (1996) were able to show that people do not compare themselves with others who are way out of their social circle. The characteristics of the reference group are gender, education and work.

As mentioned before, Stevenson and Wolfers $(2008,2013)$ challenge the 'Easterlinparadox' as they found econometric evidence for the hypothesis that increases in income would raise self-reported life satisfaction, on a country scale as well as for individuals. In a recent paper by Sacks, Stevenson and Wolfers (2013) their previous results are summarized: they believe that rich countries report high levels of life satisfaction and the relationship 
between well-being and the logarithmic form of income is mostly linear - on a country level as well as on an individual level. That means that even if personal income or country wide GDP measures reach high levels the relationship does not become flat and additional gains will further improve reported well-being. For example, similar percentage increases in GDP will generate a similar percentage rise in well-being (Sacks et al. 2013). Several studies show this with data from the Gallup World Poll which is one of the most wide ranging cross-national studies of happiness (it is used for example by Deaton 2008, Stevenson Wolfers 2008, Sacks et al. 2010, Inglehart 2008, Hagerty - Veenhoven 2003).

The results of Sacks et al. (2013) are summarized in figure 3. The left panel depicts average life satisfaction data as well as GDP per capita data ranging from 2005 to 2011 from several countries. We can see that a country with higher GDP per capita scores higher on the satisfaction score. As the fitted regression line is more or less linear but the income is in a log scale, Sacks et al. (2013) state that similar percentage increases in GDP will generate similar variations in well-being.

Next, the right panel correlates average well-being and GDP data within the world's most populous 25 countries. We can see linear "income ladders" which slope upwards. They describe how the average citizen of a country would be influenced by changes in his/her income. The upward slope indicates that richer individuals feel better.

\section{Relationship between Income and Life Satisfaction}

Figure 3
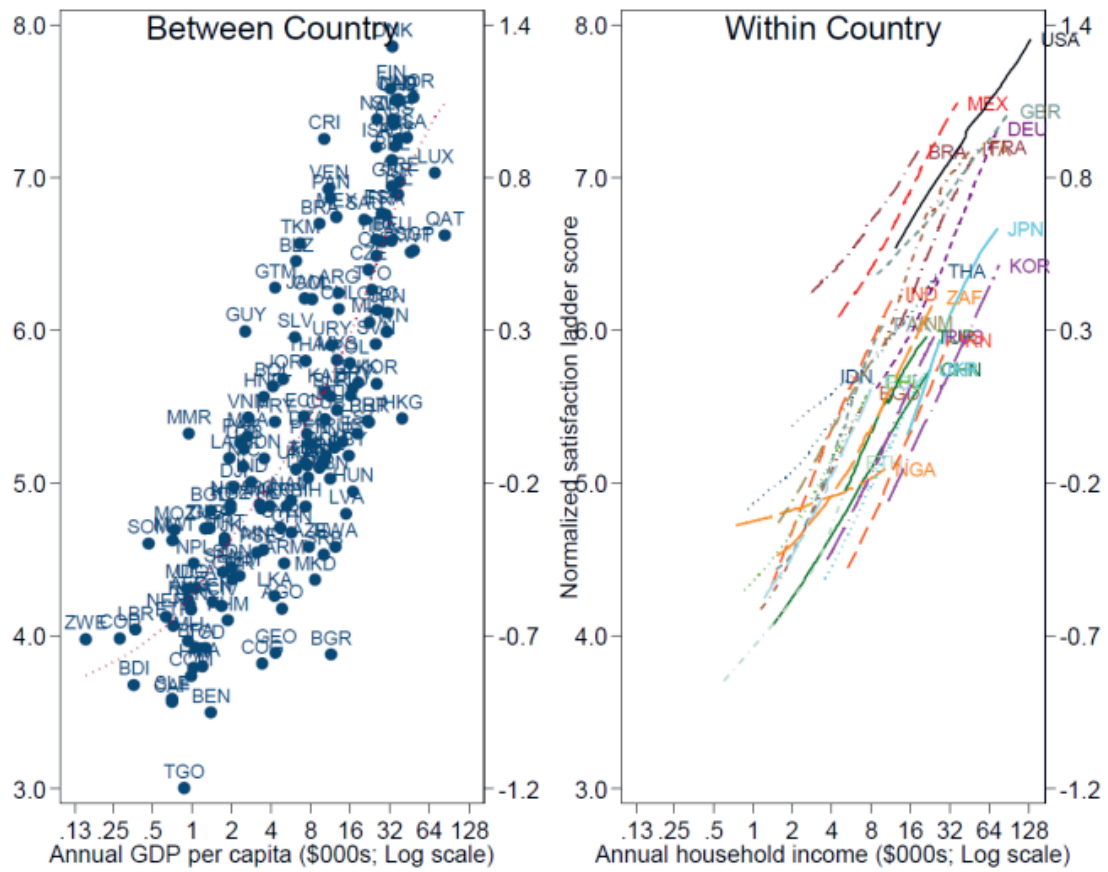

Source: Sacks et al. (2013:6).

Notes: In the left panel life satisfaction is plotted on the vertical axis and annual GDP per capita depicted as a log scale is displayed on the horizontal axis. In the right panel the normalized satisfaction ladder score is plotted on the vertical axis and annual household income depicted as a log scale is displayed on the horizontal axis. 
However, Wolfers and Stevenson admit in a New York Times (2008) interview that their "time-series evidence is fragile". Further, they just look at a short time frame and disregard the adaptation effects which might play a role in a long term comparison. Last but not least, their theory cannot clarify why some countries' life satisfaction data has remained unchanged even though GDP has risen over a long time. Interestingly, the approach of Easterlin and Stevenson/Wolfers differs in many ways for example the first uses growth rates while the second GDP levels. Besides, they even work with different datasets and different data series. Hence, their contradictory results can easily be influenced by these differences and shows the limitation of econometric research in general.

Consequently, further analysis is needed and the current research investigates the issue with new methods and new datasets. For example, Wiese (2014a) correlated life satisfaction data of European countries with the deviation of trend growth and found remarkable differences between certain countries: it seems that welfare systems and equity considerations are more important for life satisfaction than growth and income. For further reading on the general relationship between happiness and income the author suggests for instance Ahuvia and Friedman (1998), Diener and Biswas-Diener (2000), Furnham (1998) and Layard et al. (2010).

\section{Findings in connection with unemployment}

The standard view of unemployment in economics, and particularly in the New Classical Macroeconomics, is that the loss of income must be balanced against the additional amount of leisure time. Further, in a neoclassical sense involuntary unemployment cannot exist if the labor market works perfectly. However, other theories, such as New Keynesian Macroeconomics claim that the unemployed suffer. The academic debate can benefit from happiness research: For example Di Tella et al. (2003) found that the unemployed are quite negatively affected by the loss of their jobs - even if this was controlled for income effects: Their study unveils that the mere fact of not having a job leads to a reduction in life satisfaction of 0.33 points on a four point scale. Clark and Oswald (1994:655) claimed that "joblessness depressed well-being more than any other single characteristic, including important negative ones such as divorce and separation."

Similar results have been observed by other researchers for specific countries: Scandinavian countries have been studied by Darity and Goldsmith (1996), Björklund and Eriksson (1998) and Korpi (1997). Further evidence for the United Kingdom and the United States is provided by Blanchflower and Oswald (2004); Germany is covered by Winkelmann and Winkelmann (1998) and Russia by Ravallion and Lokshin (2001). All these studies show that unemployment has a negative effect on life satisfaction. Additionally, it seems that being without a job depresses to a far greater extent those who are male, highly educated and middle-aged (Clark - Oswald 1994; Clark et al. 2006).

Even though the negative relationship between unemployment and happiness seems well established the causation can be questioned: For example, unhappy people might be less effective co-workers and hence lose their jobs. Although unsatisfied workers perform worse than satisfied ones, Winkelmann and Winkelmann (1998) showed with the help of longitudinal studies that the main causation runs from unemployment to life satisfaction. Psychological and social factors seem to be the reason for the large drop in life satisfaction.

Di Tella et al. (2003) found that even people with a job are distressed by the general 
unemployment level in their country. They stated that a $1 \%$ point increase in the unemployment rate reduces life satisfaction by 0.028 units on a four-point scale. Workers might worry about the negative consequences for society and the economy. Consequently, the overall effect on society of a $1 \%$ point rise in unemployment rate can be calculated:

$$
0.33 \times 0.01+0.028=0.0313
$$

However, such calculations have to be viewed with caution as various side-effects may affect the evaluation of satisfaction. As we have seen, the reference group is an important notion in regard to life satisfaction. For instance, the social norm of having a job might be weakened if many people lose their jobs. As self-esteem can be maintained due to the fact that it is more likely a general phenomenon than one's own fault, a stabilization effect occurs.

\section{Findings in connection with inflation}

A general increase in the price level is called inflation. According to theoretical economists an anticipated increase does not bring with it any problems as adjustment can be planned beforehand. However, if inflation comes as a "shock" costs occur in the form of misallocations and prediction errors. Fischer (1981) and Lucas (1981) estimated the loss of national income to be only between 0.3 percent and 0.45 percent if yearly inflation is as high as 10 percent. The conclusion would be that inflationary policies should be considered as a tool to stimulate the economy and tackle unemployment. On the contrary most economists and central bankers believe that a low and predictable inflation rate (e.g., around 2 percent per year) is important so that economic actors can behave rationally. The picture changes if citizens are asked for their opinions, as a far-reaching study undertaken by Shiller (1997) has shown: the responses from German, American and Brazilian citizens have concentrated on the likely dangerous side effects of inflation such as the loss of purchasing power. They did not balance it with other possible positive effects e.g. higher nominal income or easier debt servicing costs. Many see great danger if the exchange rate falls as a result of inflation as the fear of political and economic chaos as well as a loss in national prestige grows.

Similarly, happiness researchers found out that inflation has adverse effects on life satisfaction. Di Tella et al. (2001) stated that if inflation increases by 1 percentage point life satisfaction is reduced by 0.01 units on a 4 point scale. Even though the effect is significant it is rather small.

The trade-off between unemployment and inflation, described, for example, in the Philips curve, can also be analyzed. Di Tella et al. (2001) stated that "the estimates suggest that people would trade off a 1-percentage-point increase in the unemployment rate for a 1.7-percentage-point increase in the inflation rate." Hence, the "Misery index" is mistaken in stating that both should be treated equal.

\section{The Value of Public Goods}

As public goods are not exchanged on markets it is difficult to derive their value. Freeman (2003) describes several approaches: the main ones are the stated preference method and 
the revealed preference method. The first one asks individuals directly via surveys about their willingness to pay. The second one tries to extract the price by analyzing the behavior of people towards complementary and substitutive goods. Both methods have several shortcomings. A new method is to use the life satisfaction approach. If the marginal utility of income is given it can be compared with the marginal utility (disutility) of a public good (bad). Hence, the trade-off ratio can be estimated. The first authors to use this approach were Van Praag and Baarsma (2004). They captured the irritation citizens living near to Amsterdam Airport had to endure as a result of noise. Another study undertaken with this method by Frey (2008) showed the effect of terrorism in France. He concludes that a "resident of Paris (with an average household income) would be willing to pay approximately 14 percent of his income for a reduction in terrorist activity to a level that prevails in the more peaceful parts of the country." Frey was able to show that life-satisfaction data is capable of estimating the negative effects of a public bad such as terrorism.

\section{Policy Consequences}

Bestselling books like "Secrets of True Happiness" and "The Art of Happiness: A Guide to Developing Life's Most Important Skill" are examples of how popular literature takes advantage of the hype around life satisfaction. An article about achieving personal happiness in the journal New Scientist (2003) distinguishes between ten factors which were ranked by leading scholars in the field. The most important five factors are presented and arranged in order of importance: Firstly, "make the most of your genes" and cultivate personality traits, which promote happiness, for example extroversion. Secondly, "make friends and value them" because this is associated with happiness with a very strong correlation. Thirdly, "desire less" so it is easier to close the aspiration gap. Fourthly, "provide help to others" because altruism and voluntary work is strongly correlated with life satisfaction. Fifthly, "be religious" as it provides purpose and meaning.

Furthermore, academics have formed a movement with the aim of conducting surveys concentrating on well-being, optimism and flow (Csikszentmihalyi 1990; Seligman 2002; Carr 2003). They call their field "positive psychology" as it focuses on valued states of mind instead of on depression or other disorders. Nettle (2005:145), for instance, proposes three suggestions for improved well-being: firstly, the influence of strong negative emotions should be weakened. Secondly, positive feelings should be built up and lastly, the adaptation to certain positive states should be averted. However, it may be true that dissatisfied individuals are the only ones unable to perform these kinds of manipulations.

This paper will also discuss important recommendations for economic policy. We have seen that the well-being of citizens is influenced by income, employment, stable prices and fair income distribution. Moreover, non-material determinants are of great importance, as is the act of volunteering. Last but not least, the evaluation of public goods can be facilitated by the Life Satisfaction Approach. These findings suggest that certain policy reforms could improve the general satisfaction of individuals. For example, as preferences are endogenous, people make systematic mistakes and hence should be guided to decisions which they desire (Easterline 2003, Layard 1980, 2006, 2007). The shortcomings of education might force additional measures such as a ban on advertisements targeted at children (Layard 2005) or even further governmental intervention. Besides, Di Tella and MacCulloch (2005) 
argue that people have problems arranging their working hours according to their optimal preferences. Some are overworked and some are unemployed because social security systems as well as taxation schemes make part time jobs disadvantageous for employees as well as employers. Improvements in this domain could free up potential satisfaction. As discussed earlier, expansionary policies could push up inflation but reduce unemployment. We have seen that citizens care more about unemployment and disregard inflation which seems to make such a policy viable. However small open economies are unable to steer these instruments well. Inflation expectations also adapt and hence the tradeoff is made impossible. Lastly, fighting terrorism and crime is an important task for all governments but they should consider different approaches towards the same end. For example deterrence of terrorist attacks such as a "war on terrorism" might entail many negative side effects for their own inhabitants. Considering alternatives such as the reintegration of possible attackers into society is more effective and causes fewer negative consequences.

To some it may be an important advice for governments to advocate the maximization of Gross National Happiness. As mentioned before, Bhutan is pursuing this goal. Bentham (1789) and Edgeworth (1881) have already argued that a national welfare function should be targeted. If such a function existed it would transform economics from a social science into something close to physics.

The advantages of such a National Happiness Indicator (NHI) in comparison to GDP would be that non-material aspects of welfare would be incorporated. Furthermore, outcome facets could determine the valuation of public goods - a great improvement compared with valuing them simply by the input side which entails only the costs. Furthermore, the evaluation of the work of the government would be possible and would reveal whether the regime really cared about the state of affairs inside the country. Lastly, a NHI would be democratic as every person would have the same weight, unlike with GDP.

However, the impossibility theorem (Arrow 1951) holds. Consequently, only a dictatorship could rank outcomes of the NHI consistently. Hammond (1991:220) states that empirical observations are not able to produce "an ethically satisfactory social welfare ordering". Additionally, classical microeconomics disregards interpersonal comparisons of utility since they are meaningless. However, psychologists claim that on a practical level this is not such a problem (Ng 1996; Kahneman 1999). Nevertheless, it is not clear whether happiness is the ultimate goal of public policy - freedom and personal development can be other ends in themselves. Besides, the attempts to maximize a NHI might trigger political problems: on the one hand, manipulations of important indicators are usual practices by governments. Examples of "creative accounting" (Jameson 1988) range from distortion of unemployment data to the alteration of the entrance criteria to the European Monetary Union: countries like Greece and Italy distorted the real values of national debt levels to a dangerous extent (Brück - Stephan 2006). On the other hand, respondents to happiness surveys might try to answer tactically so their interests are maximized. Consequently, Kahnemann et al. (2004) suggest that the NHI should merely help to inform policy makers about the changes in well-being over time, between groups or nations. However, Frey (2008:168) goes further and claims that "economic policy must (...) help to establish the fundamental institutions that lead to the best possible fulfillment of individuals' preferences". Thus, it is the authors opinion that happiness research should help institutions to be built in such a way that they allow citizens to live towards their maximum potential of life satisfaction. 


\section{Conclusion}

The valuable new insights of happiness and economics are various and contradict to a great extend the classical models of economics. Therefore, Frey (2008) called this new branch of economics revolutionary as it changed the method of research by introducing a new measure of utility. Secondly, happiness and economics can open up theoretical considerations about the right taxation as individual utility functions can be derived from surveys. Growth theory has so far neglected aspects of adaptation or social comparisons which now can be aided by empirical evidence. Thirdly, the literature has supported the ongoing research on the best public policy. The evaluation of economic tradeoffs between, for example, unemployment and inflation has been mentioned. Also, happiness research advocates certain institutional constructs such as political participation rights and federalism which seem to help citizens to better optimize their well-being (Frey - Stutzer 2002a).

However, our knowledge is still limited and findings are still debatable. This fairly young science is just beginning. Further research is needed. This paper simply wishes to highlight one example of possible future research: Wiese (2014a) found evidence that Eurozone member countries differ in their attitude towards a deviation from trend GDP growth. Portugal, Ireland, Greece and Spain showed significant and robust signs that life satisfaction was associated with the cyclical component of GDP growth indicating a recession or a boom. Other member countries were not influenced by the same kind of fluctuations. It is still questionable which parts of GDP are responsible for the variation among the country groups but Wiese (2014b) points out the effect of variations in the social welfare systems. To analyze such research questions individual life satisfaction data from the Eurobarometer report of the European Commission can be correlated with various parts of GDP and the initial model can be enriched by several economic, institutional and cultural variables.

\section{Bibliography}

Ahuvia, C.A. - Friedman, C.D. 1998. Income, consumption, and subjective well-being: Toward a composite macromarketing model. Journal of Macromarketing, 18(2), 153-168.

Allais, M. 1953. Le comportement de l'homme rationnel devant le risqué, critique des postulats et axioms de l'école Americaine. Econometrica 21: 503-546.

Arrow, K. 1951. Social Choice and Individual Values. Wiley.

BBC (2010): Plan to measure happiness 'not woolly' - Cameron, http://www.bbc.co.uk/news/uk-11833241, 30.09.2013.

Bentham, J. 1789 [1996]. An Introduction to the Principles of Morals and Legislation. Clarendon.

Björklund, A. - Eriksson, T. 1998. Unemployment and Mental Health: A Survey of Nordic Research. Scandinavian Journal of Social Welfare 7: 219-235.

Blanchflower, D. - Oswald, A. 2004. Well-Being over Time in Britain and the USA. Journal of Public Economics 88: 1359-1386.

Brennan, G. - Pettit, P. 2004. The Economy of Esteem: An Essay on Civil and Political Science. Oxford University Press.

Brickman, P. - Coates, D. - Janoff-Bulman, R.. 1978. Lottery Winners and Accident Victims: Is Happiness Relative? Journal of Personality and Social Psychology 36, no. 8: 917-927.

Brück, T. - Stephan, A. 2006. Do Eurozone Countries Cheat with Their Budget Deficit Forecasts? Kyklos 59: 3-16.

Carr, A. 2003. Positive Psychology: The Science of Happiness and Human Strength. Routledge.

Clark, A. - Oswald, A. 1994. Unhappiness and Unemployment. Economic Journal 104, no. 424: 648-659. 
Clark, A. - Oswald, A. 1996. Satisfaction and Comparison Income. Journal of Public Economics 61, no. 3: 359-381.

Clark, A - Diener, E. - Georgellis, Y. - Lucas, R. 2006. Lags and Leads in Life Satisfaction: A Test of the Baseline Hypothesis. Working paper, CNRS and DELTAFédération Jourdan.

Clark, A. - Frijters, P. - Shields, M. 2008. Relative income, happiness, and utility: An explanation for the Easterlin paradox and other puzzles. Journal of Economic Literature, 95-144.

Csikszentmihalyi, M. - Hunter, J. 2003. Happiness in Everyday Life: The Uses of Experience Sampling. Journal of Happiness Studies 4: 185-199.

Darity, W. - Goldsmith, A. 1996. I. Journal of Economic Perspectives 10, no. 1: 121-140.

De Botton, A. 2004. Status Anxiety. Hamish Hamilton.

Di Tella, R. - MacCulloch, R. - Oswald, A. 2001. Preferences over Inflation and Unemployment: Evidence from Surveys of Happiness. American Economic Review 91, no. 1:335-341.

Di Tella, R. - MacCulloch, R. - Oswald, A. 2003. The Macroeconomics of Happiness. Review of Economics and Statistics 85, no. 4: 809-827.

Di Tella, R. - MacCulloch, R. 2005. Gross National Happiness as an Answer to the Easterlin Paradox? Working Paper, Harvard Business School.

Diener, E. - Suh, E. - Lucas, R. - Smith, H. 1999. Subjective Well-Being: Three Decades of Progress. Psychological Bulletin 125, no. 2: 276-303.

Diener, E. - Diener, M. - Diener, C. 1995: Factors predicting the subjective well-being of nations. Journal of personality and social psychology, 69(5), 851.

Diener, E. - Biswas, R. - Diener, R. 2002. Will money increase subjective well-being? A literature review and guide to needed research. Social Indicators Research, 57, 119-169.

Easterlin, R. 1974. Does Economic Growth Improve the Human Lot? Some Empirical Evidence. In Nations and Households in Economic Growth: Essays in Honour of Moses Abramowitz, ed. P. David and M. Reder. Academic Press.

Easterlin, R. 2001. Income and Happiness: Towards a Unified Theory. Economic Journal 111: 465-484.

Easterlin, R. - McVey, L. - Switek, M. - Sawangfa, O. - Zweig, J. 2010. The happiness-income paradox revisited. Proceedings of the National Academy of Sciences, 107(52), 22463-22468.

Edgeworth, F. 1881. Mathematical Psychics: An Essay on the Application of Mathematics to the Moral Sciences. Kegan Paul.

Ellsberg, D. 1961. Risk, Ambiguity and the Savage Axiom. Quarterly Journal of Economics 75: 643-669.

Elster, J. 1998. Emotions and Economic Theory. Journal of Economic Literature 36, no. 1: 47-74.

Fehr, E. - Gächter, S. 1998. Reciprocity and Economics. The Economic Implications of "Homo Reciprocans." European Economic Review 42: 845-859.

Fehr, E. - Gächter, S. 2000. Fairness and Retaliation: The Economics of Reciprocity. Journal of Economic Perspectives 14: 159-181.

Fehr, E.- Schmidt, K. 2003. Theories of Fairness and Reciprocity-Evidence and Economic Applications. In Advances in Economics and Econometrics-8th World Congress, ed. M. Dewatripont, L. Hansen, and S. Turnovsky. Cambridge University Press.

Fischer, S. 1981. Towards an Understanding of the Costs of Inflation: II. Carnegie- Rochester Conference Series on Public Policy 15: 5-41.

Frank, R. 1985. Choosing the Right Pond. Oxford University Press.

Frank, R. 1999. Luxury Fever: Why Money Fails to Satisfy in an Era of Excess. Free Press.

Frederick, S. - Loewenstein R. 1999. Hedonic Adaptation. In Well-Being: The Foundations of Hedonic Psychology, ed. D. Kahneman, E. Diener, and N. Schwarz. Russell Sage Foundation.

Freeman, A. M., III. 2003. The Measurement of Environmental and Resource Values: Theory and Methods. Resources for the Future.

Frey, B. - Stutzer, A. 2002a. Happiness and Economics: How the Economy and Institutions Affect Well-Being. Princeton University Press.

Frey, B. - Stutzer, A. 2002b. What Can Economists Learn from Happiness Research? Journal of Economic Literature 40, no. 2: 402-435.

Frey, B. - Stutzer, A. 2008. Happiness - A revolution in Economics. The MIT Press, Cambridge.

Furnham, A. 1998. The psychology of money. Routledge.

Gächter, S. 2007. Conditional Cooperation: Behavioral Regularities from the Lab and the Field and Their Policy Implications. In Economics and Psychology: A Promising New Cross-Disciplinary Field, ed. B. Frey and A. Stutzer. MIT Press. 
Hammond, P. 1991. Interpersonal Comparisons of Utility: Why and How They Are and Should Be Made. In Interpersonal Comparisons of Well-Being, ed. J. Elster and J. Roemer. Cambridge University Press. Hicks, R. J. 1939: Value and Capital. London. Oxford University Press.

Irwin, F. 1944. The Realism of Expectations. Psychological Review 51: 120-126.

Jameson, M. 1988. Practical Guide to Creative Accounting. Kogan Page.

Kahneman, D. 1999. Objective Happiness. In Well-Being: The Foundations of Hedonic Psychology, ed. D. Kahneman - E. Diener - N. Schwarz. Russell Sage Foundation.

Kahneman, D. - Krueger, A. - Schkade, D. - Schwarz, N. - Stone, A. 2004. Toward National Well-Being Accounts. American Economic Review 94, no. 2: 429-434.

Keynes, J. M. 1938: Letter to Roy F. Harrod, published in Keynes, vol. XIV, pp. 299 - 301. In: Economia (2011): Keynes to Harrod http://economia.unipv.it/harrod/edition/editionstuff/rfh.346.htm [16.12.2012].

Korpi, T. 1997. Is Well-Being Related to Employment Status? Unemployment, Labor Market Policies and Subjective Well-Being among Swedish Youth. Labour Economics 4, no. 2: 125-147.

Lane, R. 1998. The Joyless Market Economy. In Economics, Values, and Organization, ed. A. Ben-Ner and L. Putterman. Cambridge University Press.

Layard, R. 1980. Human Satisfaction and Public Policy. Economic Journal 90: 737-750.

Layard, R. 2003. Happiness: Has social science a clue? London: Centre for Economic Performance.

Layard, R. 2005. Happiness: Lessons from a New Science. Penguin.

Layard, R. 2006. Happiness and Public Policy: A Challenge to the Profession. Economic Journal 116: C24C33.

Layard, R. 2007. Happiness and Public Policy: A Challenge to the Profession. In Economics and Psychology: A Promising New Cross-Disciplinary Field, ed. B. Frey and A. Stutzer. MIT Press.

Lehtonen, P. 2000. Forest Policy Review, Bhutan [World Bank (IDA) and Swiss Development Co-operation $(\mathrm{SDC})]$.

Loewenstein, G. - O’Donoghue, T. - Rabin, M. 2003. Projection Bias in Predicting Future Utility. Quarterly Journal of Economics 118: 1209-1248.

Lucas, R. Jr. 1981. Discussion of Stanley Fischer, "Towards an Understanding of the Costs of Inflation: II." Carnegie-Rochester Conference Series on Public Choice 15: 43-52.

Myers, D. 2000. The Funds, Friends, and Faith of Happy People. American Psychologist 55, no. 1: 56-67.

Nettle, D. 2005. Happiness: The Science Behind Your Smile. Oxford University Press.

New Scientist. 2003. Reasons to Be Cheerful. October 4-10: 44-47.

New York Times (2008): Maybe Money Does Buy Happiness After All http://www.nytimes.com/2008/04/16/ business/16leonhardt.html? $\mathrm{r}=0$ [13.05.2013].

Ng, Y. 1996. Happiness Surveys: Some Comparability Issues and an Exploratory Survey Based on Just Perceivable Increments. Social Indicators Research 38, no. 1: 1-27.

Osterloh, M - Frey, B. 2000. Motivation, Knowledge Transfer, and Organizational Forms. Organization Science 11, no. 5: 538-550.

Osterloh, M - Frey, B. 2004. Corporate Governance for Crooks? The Case for Corporate Virtue. In Corporate Governance and Firm Organization, ed. A. Grandori. Oxford University Press.

Osterloh, M - Frey, B. 2006. Shareholders Should Welcome Knowledge Workers as Directors. Journal of Management and Governance 10, no. 3: 325-345.

Persky, J. 1995. Retrospectives: The Ethology of Homo Economicus, The Journal of Economic Perspectives, 9(2), 221-231.

Ravallion, M. - Lokshin, M. 2001. Identifying Welfare Effects from Subjective Questions. Economica 68, no. 271: 335-357.

Sacks, D. - B. Stevenson - J. Wolfers (2010): Subjective well-being, income, economic development and growth. National Bureau of Economic Research (No. w16441).

Sen, A. 1986. The Standard of Living. In Tanner Lectures on Human Values, volume VII, ed. S. McMurrin. Cambridge University Press.

Shiller, R. 1997. Why Do People Dislike Inflation? In Reducing Inflation: Motivation and Strategy, ed. C. Romer and D. Romer. University of Chicago Press.

Schwarze, J. - Winkelmann, R. 2005. What Can Happiness Research Tell Us about Altruism? Evidence from the German Socio-Economic Panel. Discussion Paper 1487, IZA (Institute for the Study of Labor), Bonn.

Seligman, M. 2002. Authentic Happiness. Free Press. 
Sirgy, M. J. 1997. Materialism and Quality of Life. Social Indicators Research 43, no. 3: 227-260.

Stevenson, B. - Wolfers, J. 2008: Economic growth and subjective well-being: Reassessing the Easterlin paradox National Bureau of Economic Research.

Stevenson, B. - Wolfers, J. 2013: Subjective Well-Being and Income: Is There Any Evidence of Satiation? National Bureau of Economic Research.

Szondy, M. 2004: A szubjektív jóllét és a törekvések kapcsolata késő serdülőkorban. Alkalmazott Pszichológia. $6(4)$, pp. $53-72$.

The Telegraph (2009): Nicolas Sarkozy wants to measure economic success in 'happiness', http://www. telegraph.co.uk/news/worldnews/europe/france/6189530/Nicolas-Sarkozy-wants-to-measureeconomic-success-in-happiness.html, 30.09.2013.

Van Praag, B. - Baarsma, B. 2004. Using Happiness Surveys to Value Intangibles: The Case of Airport Noise. Economic Journal 115, no. 500: 224-246.

Van Praag, B. - Frijters, P. 1999. The Measurement of Welfare and Well-Being: The Leyden Approach. In Well-Being: The Foundations of Hedonic Psychology, ed. D. Kahneman, E. Diener, and N. Schwarz. Russell Sage Foundation.

Veenhoven, R. 1991. Is happiness relative? Social Indicators Research, 24(1), 1-34.

Wiese, T. 2014a. Analysis of the Trend Growth of GDP and Life Satisfaction in the EMU. Accepted in (2013) and forthcoming in Acta Oeconomica.

Wiese, T. 2014b. Explanation of the Trend Growth of GDP and Life Satisfaction in the EMU: The Impact of Welfare Regimes. Accepted in (2014) and forthcoming in Society and Economy.

Winkelmann, L. - Winkelmann, R. 1998. Why Are the Unemployed So Unhappy? Evidence from Panel Data. Economica 65, no. 257: 1-15. 